\title{
The Impact of Organizational Justice, Self-Efficacy and Teachers Performance: The Mediating Role of Internal Motivation
}

\author{
Sopiah $^{1}$, Etta Mamang Sangadji ${ }^{2}$, Bagus Shandy Narmaditya ${ }^{3}$ \\ State University of Malang, Faculty of Economics, Jalan Semarang 5 Malang, ID-65145, Indonesia, sopiah.fe@um.ac.id \\ PGRI Wiranegara University, Graduate Program of Economic Education, Jalan Ki Hajar Dewantoro 27-29, \\ Pasuruan, Indonesia, sangadji_23@yahoo.com \\ 3 State University of Malang, Faculty of Economics, Jalan Semarang 5 Malang, ID-65145, Indonesia, bagus.shandy.fe@ \\ um.ac.id
}

Annotation. This study examines the impact of organizational justice and self-efficacy on teachers' performance in Indonesia and the role of internal motivation. Using path analysis, the findings indicate that both organizational justice and self-efficacy can affect teacher performance and correlate with internal motivation. Additionally, internal motivation plays a role as a partial mediating relationship between organizational justice and teacher performance, as well as mediating self-efficacy and teacher's performance.

Keywords: internal motivation, organizational justice, self-efficacy, teacher's performance.

\section{Introduction}

The topic of employee performance has gained consideration among scholars for more than a decade in many countries. For instance, Kalay (2016) demonstrated the role of organizational justice and employee performance in Turkey, while Iqbal et al. (2017) have focused on employee performance in the context of Pakistani. In the health sector, Dajani and Mohamad (2017) examined the factors affecting nurses' performance in Mesir. Meanwhile, in the educational sector, the topic of teacher performance has investigated in India by Muralidharan and Sundararaman (2011), in Malaysia was performed by Gallant and Mayer (2012), and in Indonesia was highlighted by Suratman et al. (2020). 
Teacher performance plays a central role in the success and failure of education. Teacher with high performance is linked by having excellent competencies that lead to students' accomplishment and vice versa (Bakar, 2018; Gonzalez \& Maxwell, 2018). Additionally, Kaur (2017) noted a significant impact of a high-quality teacher on social and economic matters. Having a high-performance teacher is needed to ensure the quality of education. The teacher certification program aims to ensure that teachers have adequate competencies required for teaching. However, Kusumawardhani (2017) noted that the teacher certification program has no substantial impact on teacher performance as well as student achievement.

This is arguable that an essential question continually confronted by Indonesian governments is how to enhance the teachers' performance. The fundamental rationale is that insufficient teacher performance certainly worries many parties, starting from parents, teachers, principals, heads of city or district education offices, and even provincial education offices. For this reason, all components related to education, particularly in East Java, are expected to contribute to finding solutions to these issues. In general, employee performance can be determined by several factors such as organizational justice (Mehmood \& Ahmad, 2016; Durrani, 2019), internal motivation (Ali et al., 2016; Makki \& Abid, 2017), self-efficacy (Etehadi \& Karatepe, 2019; De Clercq et al., 2018).

The contributions of this study are twofold. First, this present study contributes to the existing literature by engaging several variables such as organizational justice, selfefficacy, and internal motivation. These variables are widely used to understand employee performance in general, such as in the nursing profession (Osei et al., 2017), in civil servant employee (Gani et al., 2019), banking profession (Niazi \& Hassan, 2016), while few studies which investigated the teacher performance (Shan et al., 2015). Also, the growing studies of teacher performance in Indonesia are mainly linked with teacher profession programs (e.g., Kusumawardhani, 2017; Bakar, 2018; Suratman et al., 2020). Second, this study aims to lift concepts and theories that are mostly applied in the business field into the context of education. This work is expected to contribute to the school principal and provincial education office to provide considerable performance improvement policies from the managerial perspectives.

\section{Literature Review}

\section{Organizational Justice}

Organizational justice refers to employee equality in an organization (Gibson et al., 2012). Colquitt et al. (2001) added that organizational justice covers four principal aspects: distributive, procedural, interpersonal, and informational justice. Similarly, Musringudin et al. (2017) demonstrated indicators in organizational justice, namely justice in 
reasonable resource allocation, decision-making process, and in the perception of fairness over maintaining interpersonal relationships. Some previous literature remarked that organizational justice can explain working motivation. For instance, Ghazi and Jalali (2017) showed that organizational justice affects employees' work motivation in Tehran. Internal motivation covers the work itself, work performance, responsibilities, recognition, and promotion (Herzberg et al., 1959). In addition, Akram et al. (2020) confirmed that organizational justice could influence employees' work motivation in a company in China.

On the other hand, the relationship between organizational justice and employee performance has been widely examined among scholars. For example, Iqbal (2017) mentioned that organizational justice can explain the more exceptional performance of employee performance in Pakistan's public sector. Other studies by Ali et al. (2016); Ismail and Razaq (2017); Suliman and Kathairi (2013) confirmed the correlation between organizational justice and organizational performance. Indeed, in the education sector, Mehmood and Ahmad (2016) have documented a positive impact of organizational justice (distributive, procedural, and interactional justice) on teacher performance in Pakistan.

H1: Organizational justice positively influences teacher performance.

$\mathrm{H} 2$ : Organizational justice positively influences internal motivation.

\section{Self-Efficacy}

Self-efficacy plays a crucial role in explaining the success or failure of human behavior (Schunk, 2016). Self-efficacy is self-confidence in regulating motivation, thought processes, and the environment to achieve certain goals. Several studies mentioned a correlation between self-efficacy and work motivation (Stajkovic \& Luthans, 2003; Canrinus et al., 2012). Furthermore, employees with low self-efficacy levels will have negative thoughts and consider the task's demands as a threat, not as a challenge. This has an impact on setting low goals as well as low motivation. In addition, self-efficacy is also can determine employee performance (Stajkovic et al., 2018). Preliminary studies mentioned that employees with high self-efficacy are likely to focus more on their work, leading to greater performance (Bhatti et al., 2018). Indeed, De Clerq et al. (2018) pointed out that the employee can also provide better performance despite insufficient work circumstances. Other studies also confirmed the positive relationship between self-efficacy and employee performance (Judge et al., 2017; Carter et al., 2018; Walumbwa \& Hartnell, 2011; Chemens et al., 2001; Yusuf, 2011).

H3: Self-efficacy positively influences teacher performance.

H4: Self-efficacy justice positively influences internal motivation.

\section{The Moderating Role of Work Motivation}

The growing study of the literature showed that work motivation can explain employee performance (Özutku, 2012; Khan et al., 2013; Salleh et al., 2011; Zhang et al., 2015). Besides, Wang et al. (2010) added that work motivation directly affects employee 
performance and plays an essential role in mediating organizational justice and employee performance. Indeed, Hannam and Naraya (2015) showed that organizational justice mediates between intrinsic motivation and employee creativity. Similarly, Ugaddan and Park (2019) confirmed that public service motivation and extrinsic motivation partially mediate the relationship of trust in leadership and organizational justice and whistle-blowing intention. On the other hand, motivation can also mediate self-efficacy and job performance. A prior study by Miraglia (2017) showed the role of job-crafting (highly motivated employee) in mediating self-efficacy and employee performance. Other studies confirmed the role of working motivation in explaining the relationship between leadership justice and employee performance (e.g., Yusof, 2011; Lunenburg, 2011; Cetin \& Askun, 2018).

$\mathrm{H} 5$ : Work motivation positively influences teacher performance.

H6: Organizational justice influences teacher performance through work motivation.

H7: Self-efficacy influences teacher performance through work motivation.

\section{Method}

\section{Research design}

This study applied a quantitative method using path analysis. This method is particularly useful in understanding the relationship among variables and knowing the role of moderating variables. This study involves significant variables, including organizational justice, self-efficacy, internal motivation, teacher performance. In more detail, the framework of the study is provided in Figure 1.

\section{Figure 1}

The Research Framework

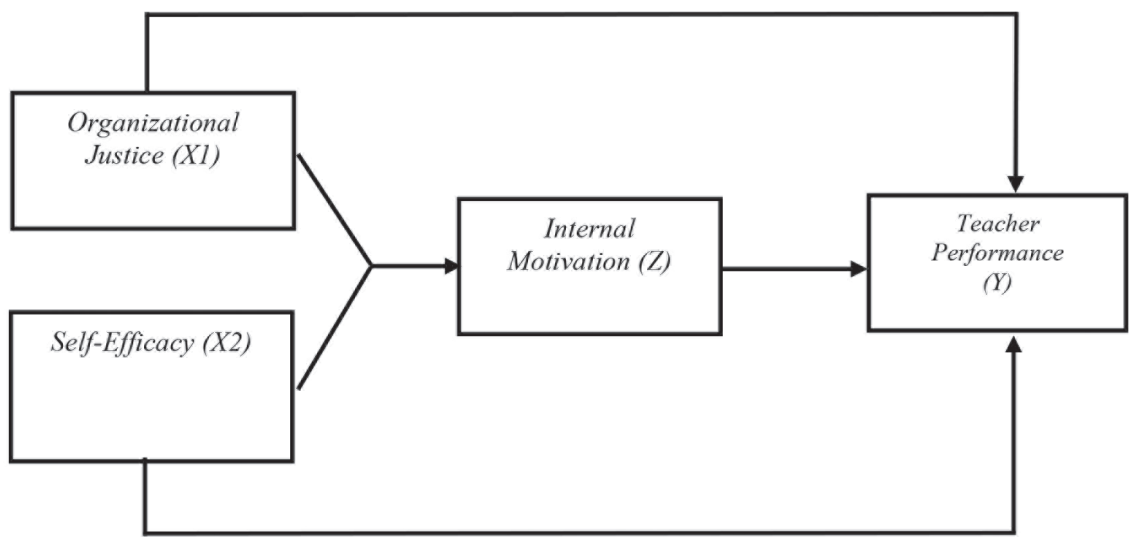




\section{Population and Sample}

The population of this study was vocational school teachers in East Java of Indonesia. The focused study in East Java of Indonesia is rational, considering the vocational schools in East Java have more sufficient educational facilities and infrastructure than other provinces in Indonesia. Stratified random sampling was engaged in this study to gain a better understanding of the variables studied. The work was conducted during March and July 2020 by using online questionnaires. A total of 400 questionnaires were returned, and after separating with 50 of missing data, approximately 350 responses from participants can be used for further analysis. From the collection, the majority of respondents were 48 percent is male, and the rest percentage were female. The educational background of the teacher is that most vocational teachers were graduated with a bachelor's degree, while a small percentage of teachers were graduated from master's (8\%) and doctoral programs (1\%). In addition, the majority of respondents have 10 to 20 years of work experience and have married. This study applied a closed-questionnaire undergoing Likert scale with five alternative answer choices (score $5=$ strongly agree, value $4=$ agree, value $3=$ neutral, value 2 = disagree, value 1 = strongly disagree.

\section{Measurements and Data analysis}

This study has four variables, namely, organizational justice and self-efficacy as an independent variable, internal motivation as a mediator variable, and teacher performance as the dependent variable. Indicators for measuring teacher performance refer to Bakar (2018), including pedagogical competencies, personal competencies, social competencies, and professional competencies. Additionally, self-efficacy was adopted items from Schwarzer and Jerusalem (1995), and organizational justice was measured by questionnaires from Van Dyne et al. (1994); Cropanzo et al. (2007). Lastly, the internal motivation variable included the work itself, work performance, responsibilities, and promotion, which was adopted from Herzberg et al. (1959); Sopiah (2008). Accordingly, the data were analyzed with descriptive analysis and inferential analysis (with path analysis). Before the path analysis, the classic assumption test was used, which including, the normality test and multicollinearity test, and the Heteroscedasticity test.

\section{Results and Discussion}

\section{Hypothesis Testing}

Table 1 informs the results of hypothesis testing using regression analysis. From the table, it can be known that the standardized beta coefficient of X1 is 0.223 , with a sig $\mathrm{t}$-value $=0.000<0.05$. It implies that the first hypothesis is accepted. The next four 
hypotheses range from between 0.236 to 0.282 , with a significant level of 0.000 . These results showed that all variables can explain the dependent variable. However, the indirect impact of internal motivation cannot explain two independent variables, which are organizational justice and self-efficacy, with a score of 0.065 and 0.075 , respectively. The value of the indirect effect is smaller than the direct effect, thus the function of the internal motivation variable in the relationship between organizational justice, selfefficacy variables, and teacher performance is weakening.

Table 1

The Summary of Results Analysis

\begin{tabular}{llcccc}
\hline & \multicolumn{1}{c}{ Variables } & Direct Impact & Indirect Effect & Total & Sig. \\
\hline $\mathrm{H} 1$ & $\mathrm{OJ} \rightarrow \mathrm{TP}$ & .223 & - & .223 & .000 \\
$\mathrm{H} 2$ & $\mathrm{OJ} \rightarrow \mathrm{IM}$ & .241 & - & .241 & .001 \\
$\mathrm{H} 3$ & $\mathrm{SE} \rightarrow \mathrm{TP}$ & .236 & - & .236 & .001 \\
$\mathrm{H} 4$ & $\mathrm{SE} \rightarrow \mathrm{IM}$ & .282 & - & .282 & .000 \\
$\mathrm{H} 5$ & $\mathrm{IM} \rightarrow \mathrm{TP}$ & .269 & - & .269 & .000 \\
$\mathrm{H} 6$ & $\mathrm{OJ} \rightarrow \mathrm{IM} \rightarrow \mathrm{TP}$ & .223 & .065 & .288 & \\
$\mathrm{H} 5$ & $\mathrm{SE} \rightarrow \mathrm{IM} \rightarrow \mathrm{TP}$ & .241 & .075 & .316 & \\
\hline
\end{tabular}

Note. $\mathrm{OJ}=$ organizational justice; $\mathrm{SE}=$ self-efficacy; $\mathrm{IM}=$ internal motivation; $\mathrm{TP}=$ teacher performance

Organizational justice is perceived as high by vocational teachers. According to Van Dyne et al. (1994); Cropanzo et al. (2007), organizational justice refers to the same opportunity to use the school's possessions, given equal opportunity to voice ideas, all teachers are treated equally by the school principals, and information is transmitted to all teachers. Meanwhile, the intrinsic motivation of vocational school teachers is categorized as high. The teacher with a high internal motivation has several characteristics, including proud of their work has an important meaning in their life, proud of their performance, proud of being given responsibility, proud because the school principal appreciates their performance. Also, self-efficacy and teacher performance is favorably perceived by school principals. Teacher performance is measured by four competence, including pedagogical, professional, social, and personal competence.

\section{Organizational Justice and Teacher Performance}

The finding of the study showed that organizational justice positively influences vocational teacher performance. The results of this study support a prior study by Altahayneh et al. (2014), who mentioned that organizational justice had a positive effect on the performance of physical education teachers in Jordan. This finding is also in agreement with some previous studies by Shan et al. (2015); Iqbal et al. (2017); Ali et al. (2016); Wang et al. (2010), which mentioned a positive correlation between organizational justice and 
employee performance. Organizational justice is indeed enforced for all teachers and staff, such as standardization of workload by considering their expertise, equal treatment of all teachers in terms of an individual development program, application of rules and rewards for teachers in schools. Similarly, the vocational school teachers believe that equality occurred when they provided the performance, including knowledge, energy, and time, to obtain equivalent results, both material and non-material. Second, the appreciation of both material and non-material is obtained following fair and transparent procedures. Third, the school principals deal with the teachers undergoing the humanist approach. Lastly, this finding pointed out that when justice has perceived highly by the teachers, it will lead to the more significant teacher performance that will drive the organization's success.

\section{Organizational Justice and Internal Motivation}

The results of the study confirm that organizational justice has a significant positive effect on teachers' internal motivation. Teachers who feel treated fairly by the principal will have high internal motivation. Teachers have experienced fair organizational justice with salaries that are in line with workload and performance. Implemented good positive and negative reinforcement procedures, consistent application of regulations, no discrimination in the application of regulations, and policies that are implemented based on accurate information. Treatment of school principals politely, full of dignity, respect, refrain from saying inappropriate, transparent in communicating, explain the rules thoroughly, and willing to communicate whenever needed. According to Sopiah (2008), internal or intrinsic motivation (e.g., work itself, achievement, recognition, responsibility, advancement) has a direct effect on an individual or organizational performance. While extrinsic motivation (e.g., salary, supervision, relationships with colleagues, institutional rules, working conditions) will solely make teachers' or employees' welfare. Even if, for example, salaries increase, performance may rise slightly and temporarily, in the end, the teacher will perform as before because the salary is a significant factor that only increases employee performance temporarily or temporarily. In general, justice is described as a social condition when norms regarding rights and eligibility are met (Lind \& Tyler, 1988). Indeed, this finding agrees with Akram et al. (2020), who remarked that organizational justice influences the innovative work behavior of telecommunications company employees in China. Knowledge sharing mediates the relationship between organizational justice and innovative work behavior of employees. Similarly, Ghazi and Jalali (2017); Wang et al. (2010) revealed that organizational justice influences employee work motivation in Tehran and China.

\section{Self-Efficacy and Teacher Performance}

The next finding of this study showed that self-efficacy affects the performance of vocational school teachers. This study shows that an adequate level of self-efficacy from 
vocational teachers is shown in confidence in their ability to carry out tasks that affect performance, where teachers are always obedient to the institution's procedures and can always cooperate with others in completing work. The result of this work is in line with the findings of Stajkovic et al. (2018) that self-efficacy influences employee performance. It implies that a high level of self-efficacy will lead to more significant employee performance. In fact, employees with high efficacy tend to focus more on the job and lead to better performance. This study also corroborates with previous studies by Bhatti et al. (2018); De Clerq et al. (2018); Judge et al. (2017); Liana et al. (2016); Chemens et al. (2001); Mukrodi (2018); Mujanah (2020) which confirmed that self-efficacy can explain the greater teachers' performance. Having high-level self-efficacy implies that teachers have a robust belief about their potential and performance. In addition, teachers with a high level of self-efficacy can deal with the issues in the school and the learning process in the classroom.

\section{Self-Efficacy and Internal Motivation}

The next hypothesis of the study found a significant impact between self-efficacy and internal motivation. Self-efficacy is confidence in regulating motivation, thought processes, and the environment to achieve specific goals (Schunk, 2016). Self-efficacy emphasizes that human success or failure depends on how intense the interaction between thoughts and tasks. Self-efficacy affects a number of aspects of human behavior. Employees with low self-efficacy will have negative thoughts and consider task demands as a threat, not as a challenge; this will impact setting goals that are low and lead to unsatisfactory performance (Schunk, 2016). This finding also supports prior studies by Lunenburg (2011); Stajkovic and Luthans (2003); Canrinus et al. (2012), which remarked that self-efficacy has a positive impact on employee motivation. The finding implies that the vocational school teachers with a high self-efficacy have impacted to confidence in their abilities, the confidence to overcome problems as difficult, and as much as anything, always able to find alternative solutions to problems that will undoubtedly have high internal motivation. The finding of this study indicate that the teacher's internal motivation will emerge when the teacher is proud of his/her work, the teacher is satisfied because they are given responsibility in accordance with the rank or position, the teacher is satisfied with his/ her performance, the teacher is satisfied because he/she obtains the recognition of their performance. Additionally, the teacher is satisfied because they have the opportunity to grow and develop his/her personal and professional.

\section{Internal Motivation and Teacher Performance}

This study also found that internal motivation successfully impacts vocational teacher performance. The study indicates that a high internal motivation of teachers is formed from inner attitudes facing work situations is the energies that move that aim to achieve organizational goals. That attitude positive about the work circumstance is what 
strengthens his/her work motivation to achieve maximum performance. This result is in agreement with some works by Özutku (2012); Khan et al. (2013); Salleh et al. (2011), which confirmed this relationship. The intrinsic motivation of teachers is proxied by work itself, work performance, responsibilities, and recognition. The finding of this study suggests that the teachers who are proud of their work, accomplishments, responsibilities, existence, and performance tend to have high intrinsic motivation. Conversely, teachers who feel objectively that they are not treated fairly by institutions/school principals tend to have insufficient internal motivation, are not satisfied, and are prepared to leave the organization if there are better opportunities and opportunities outside. Teachers who are satisfied because of work itself, recognition, achievement, responsibility, advancement will have a strong drive within themselves to perform optimally. Instead, low teacher performance will be owned by teachers who are not proud of their work, are not given responsibility, are not valued by their existence and performance, not given the opportunity to grow and develop.

\section{Organizational Justice, Internal Motivation and Teacher Performance}

Internal motivation cannot fully mediate the relation between organizational justice and teacher performance. In fact, internal motivation weakens the effect of organizational justice and teacher performance. Therefore, the direct effect of organizational justice on teacher performance is more significant than the path of influence through internal motivation. This finding is in line with Wang et al. (2010), who remarked that organizational justice influences performance and organizational justice could affect performance through leader-member exchange and organizational commitment. Indeed, Ghazi and Jalali (2017) prove that organizational justice influences satisfaction and loyalty through behavior organizational citizenship. The results of the study implicitly indicate that organizational justice influences employee performance. Employee satisfaction and loyalty will not be obtained when the teacher is not performing high. High-performing teachers tend to be satisfied that will lead to more outstanding commitment, and will not leave the school where they work. Therefore, teachers who feel and are treated fairly by organizations or leaders tend to perform high. The role of internal motivation as partial mediating shows the function of internal motivation, which weakens the relationship of organizational justice with teacher performance. For this matter, the recommended path is the direct relationship of organizational justice with teacher performance. Many empirical studies prove the effect of organizational justice on organizational performance instead of individual or group performance.

\section{Self-Efficacy, Internal Motivation, and Teacher Performance}

The last finding of the study showed that internal motivation unsuccessfully explains the impact of self-efficacy and vocational teacher performance. This finding confirms a prior study by Ayundasari et al. (2017), which proves that self-efficacy influences 
performance through job satisfaction. Similarly, Pajares and Graham (1999); Dabas and Pandey (2015); Monika and Adman (2017); revealed that self-efficacy and motivation have a positive effect on performance directly, not through intermediaries. Indeed, Lunenburg (2011) remarked that self-efficacy plays a role in improving employee motivation and performance. Furthermore, there are many empirical studies that prove that self-efficacy has a direct effect on teacher performance, only one research result shows that self-efficacy influences performance through internal motivation and the role of internal motivation as partial mediating (Cetin \& Askun, 2018).

\section{Conclusion}

This study investigated the impact of organizational justice and self-efficacy toward teachers' performance in Indonesia, as well as understand the role of internal motivation. Teachers and school principals highly perceive the variables in this study, including organizational justice, self-efficacy, internal motivation, and teachers' performance. The finding of the study showed that both organizational justice and self-efficacy can affect teacher performance. Indeed, the high internal motivation can also explain the teacher's performance. Also, both organizational justice and self-efficacy correlate with internal motivation. Internal motivation plays the role of a partial mediating relationship between organizational justice and teacher performance. Indeed, internal motivation acts as a partial mediating relationship between self-efficacy and teacher performance. Referring to these findings, it is suggested to school principals and policymakers in Indonesia to pay attention to the improvement of organizational justice, self-efficacy, and internal motivation of teachers due to this significant role in affecting the better performance as well as teacher certification program.

\section{References}

Akram, T., Lei, S., Haider, M. J., \& Hussain, S. T. (2020). The impact of organizational justice on employee innovative work behavior: Mediating role of knowledge sharing. Journal of Innovation \& Knowledge, 5(2), 117-129. https://doi.org/10.1016/j.jik.2019.10.001

Ali, A., Bin, L. Z., Piang, H. J., \& Ali, Z. (2016). The impact of motivation on the employee performance and job satisfaction in its park (software house) sector of Peshawar, Pakistan. International Journal of Academic Research in Business and Social Sciences, 6(9), 297-310. http://dx.doi.org/10.6007/IJARBSS/v6-i9/2311

Ayundasari, D. Y., Sudiro, A., \& Irawanto, D. W. (2017). Improving employee performance through work motivation and self-efficacy mediated by job satisfaction. Jurnal Aplikasi Manajemen, 15(4), 587-599. 
Bakar, R. (2018). The influence of professional teachers on Padang vocational school students' achievement. Kasetsart Journal of Social Sciences, 39(1), 67-72. https://doi.org/10.1016/j. kjss.2017.12.017

Canrinus, E. T., Helms-Lorenz, M., Beijaard, D., Buitink, J., \& Hofman, A. (2012). Self-efficacy, job satisfaction, motivation and commitment: Exploring the relationships between indicators of teachers' professional identity. European Journal of Psychology of Education, 27(1), 115-132. https://doi.org/10.1007/s10212-011-0069-2

Carter, W. R., Nesbit, P. L., Badham, R. J., Parker, S. K., \& Sung, L. K. (2018). The effects of employee engagement and self-efficacy on job performance: a longitudinal field study. The International Journal of Human Resource Management, 29(17), 2483-2502. https:/doi.org/ 10.1080/09585192.2016.1244096

Çetin, F., \& Aşkun, D. (2018). The effect of occupational self-efficacy on work performance through intrinsic work motivation. Management Research Review, 41(2), 186-201. https:// doi.org/10.1108/MRR-03-2017-0062

Chemens, M. M., Hu, L. \& Garcia, B. F. (2001). Academic self-efficacy \& first year college student performance and adjustment. Journal of Educational Psychology, 93, 55-64. https://psycnet. apa.org/doi/10.1037/0022-0663.93.1.55

Colquitt, J. A., LePine, J. A., \& Wesson, M. J. (2009). Organizational behavior: Improving performance and commitment in the workplace. United States: McGraw-Hill.

Cropanzano, R., Bowen, D. E., \& Gilliland, S. W. (2007). The management of organizational justice. Academy of Management Perspectives, 21(4), 34-48. https://doi.org/10.5465/ amp.2007.27895338

Dajani, M. A. Z., \& Mohamad, M. S. (2017). The mediating role of work values in the relationship between islamic religiosity and job performance: Empirical evidence from Egyptian public health sector. Journal of Business Theory and Practice, 5(4), 293. http://dx.doi.org/10.22158/ jbtp.v5n4p293/ojs/index.php/jbtp

De Clercq, D., Haq, I. U., \& Azeem, M. U. (2018). Self-efficacy to spur job performance. Management Decision, 56(4), 891-907. https://doi.org/10.1108/MD-03-2017-0187

Durrani, T. I. K. (2019). Factors affecting teacher's performance: Evidence from private Secondary Schools of Karachi. RADS Journal of Business Management, 1(2), 67-77.

Etehadi, B., \& Karatepe, O. M. (2019). The impact of job insecurity on critical hotel employee outcomes: The mediating role of self-efficacy. Journal of Hospitality Marketing \& Management, 28(6), 665-689. https://doi.org/10.1080/19368623.2019.1556768

Gallant, A., \& Mayer, D. (2012). Teacher performance assessment in teacher education: An example in Malaysia. Journal of Education for Teaching, 38(3), 295-307. https://doi.org/10. 1080/02607476.2012.668330

Gani, M. U., Ghani, A., \& Nujum, S. (2019). Leadership and local culture influence on state civil apparatus' (ASN) job satisfaction and performance at Soppeng regional organization. Social Science and Humanities Journal, 1326-1345. 
Ghazi, M., \& Jalali, S. M. (2017). The effects of organizational justice and job motivation on organizational citizenship behavior and its impact on taxpayers. Revista Administração em Diálogo-RAD, 19, 39-61. https://doi.org/10.20946/rad.v19i0.31990

Gibson, J. L., Donnelly, J. H., Ivancevich, J. M., \& Konopaske, R. (2012). Organizations: Behavior, structure, processes. Singapore: McGraw-Hill.

Gonzalez, K., \& Maxwell, G. M. (2018). Mathematics teachers' efficacy, experience, certification and their impact on student achievement. Journal of Instructional Pedagogies, 21, 1-11.

Hannam, K., \& Narayan, A. (2015). Intrinsic motivation, organizational justice, and creativity. Creativity Research Journal, 27(2), 214-224. https://doi.org/10.1080/10400419. 2015.1030307

Heck, R. H. (2009). Teacher effectiveness and student achievement: Investigating a multilevel cross-classified model. Journal of Educational Administration, 47(2), 227-249. https://doi. org/10.1108/09578230910941066

Herzberg, F. A., Mausner, B., \& Snyderman, B. (1959). The motivation to work. New York: Wiley. Iqbal, M. Z., Rehan, M., Fatima, A., \& Nawab, S. (2017). The impact of organizational justice on employee performance in public sector organization of Pakistan. International Journal of Economics \& Management Sciences, 6(3), 1-6. https://doi.org/10.4172/2162-6359.1000431

Ismail, A., \& Razak, A. M. R. (2017). Performance-based reward administration as an antecedent of job satisfaction: A case study of Malaysia’s fire and rescue agencies. Geografia-Malaysian Journal of Society and Space, 12(7), 107-118.

Judge, T. A., Weiss, H. M., Kammeyer-Mueller, J. D., \& Hulin, C. L. (2017). Job attitudes, job satisfaction, and job affect: A century of continuity and of change. Journal of Applied Psychology, 102(3), 356-374. https://doi/10.1037/apl0000181

Kalay, F. (2016). The impact of organizational justice on employee performance: A survey in Turkey and Turkish context. International Journal of Human Resource Studies, 6(1), 1-20. http://dx.doi.org/10.5296/ijhrs.v6i1.8854

Kaur, B. (2017). Social and economic values of prospective teachers in relation to attitude towards teaching profession. International Education and Research Journal, 3(5), 167-168.

Khan, I., Shahid, M., Nawab, S., \& Wali, S. S. (2013). Influence of intrinsic and extrinsic rewards on employee performance: The banking sector of Pakistan. Academic Research International, 4(1), $282-291$.

Kusumawardhani, P. N. (2017). Does teacher certification program lead to better quality teachers? Evidence from Indonesia. Education Economics, 25(6), 590-618. https://doi.org/10.1080/096 45292.2017.1329405

Lind, E. A., \& Tyler, T. R. (1988). Critical issues in social justice. The social psychology of procedural justice. New York, NY, US.

Lunenburg, F. C. (2011). Self-efficacy in the workplace: Implications for motivation and performance. International Journal of Management, Business, and Administration, 14(1), 1-6. 
Makki, A., \& Abid, M. (2017). Influence of intrinsic and extrinsic motivation on employee's task performance. Studies in Asian Social Science, 4(1), 38-43. http://dx.doi.org/10.5430/sass. v4n1p38

Mehmood, N., \& Ahmad, U. N. U. (2016). Organizational Justice and employee performance: Evidence from higher education sector in Pakistan. Jurnal Kemanusiaan, 14(2), 48-56.

Monika, M., \& Miraglia, M., Cenciotti, R., Alessandri, G., \& Borgogni, L. (2017). Translating self-efficacy in job performance over time: The role of job crafting. Human Performance, 30(5), 254-271. https://doi.org/10.1080/08959285.2017.1373115

Adman, A. (2017). Peran efikasi diri dan motivasi belajar dalam meningkatkan hasil belajar siswa sekolah menengah kejuruan. Jurnal Pendidikan Manajemen Perkantoran (JPManper), 2(2), 219-226.

Mujanah, S. (2020, January). The effect of self-efficacy, competence, and emotional quotient on employee performance through career development as an intervening variable on companies. In 17th International Symposium on Management (INSYMA 2020) (pp. 58-62). Atlantis Press.

Mukrodi, M., \& Reza, M. (2018). Pengaruh efikasi diri terhadap kinerja karyawan pt express kencana lestari (express group) depok. Kreatif: Jurnal Ilmiah Prodi Manajemen Universitas Pamulang, 6(1), 88-94. http://dx.doi.org/10.32493/jk.v6i1.y2018.p88-94

Mundhra, W. C. D. (2010). Intrinsic motivational canvass in the Indian service sector: An empirical study. Vision, 14(4), 275-284. https://doi.org/10.1177\%2F097226291001400404

Muralidharan, K., \& Sundararaman, V. (2011). Teacher performance pay: Experimental evidence from India. Journal of political Economy, 119(1), 39-77.

Musringudin, M., Akbar, M., \& Karnati, N. (2017). The effect of organizational justice, job satisfaction, and organizational commitment on organizational citizenship behavior (OCB) of the principles. IJER-Indonesian Journal of Educational Review, 4(2), 155-165. https://doi. org/10.21009/IJER.04.02.17

Niazi, A., \& Hassan, H. (2016). Effect of justice on employee performance in the banking sector of Pakistan. Pakistan Journal of Commerce and Social Sciences (PJCSS), 10(3), 735-752.

Osei, H. V., Osei-Kwame, D., \& Osei Amaniampong, L. (2017). The effects of individual mechanisms on work self-efficacy of nurses: the mediating role of organisational commitment. International Journal of Healthcare Management, 10(4), 219-237. https://doi.org/10.1080/20479700.2016. 1268798

Özutku, H. (2012). The influence of intrinsic and extrinsic rewards on employee results: An empirical analysis in Turkish manufacturing industry. Business and Economics Research Journal, 3(3), 29-48.

Pajares, F., \& Graham, L. (1999). Self-efficacy, motivation constructs, and mathematics performance of entering middle school students. Contemporary educational psychology, 24(2), 124-139. https://doi.org/10.1006/ceps.1998.0991

Salleh, F., Dzulkifli, Z., Abdullah, W. A. W., \& Yaakob, N. H. M. (2011). The effect of motivation on job performance of state government employees in Malaysia. international Journal of Humanities and social science, 1(4), 147-154. 
Schunk, D. H., \& Dibenedetto, M. K. (2016). Self-efficacy theory in education. Handbook of motivation at school, 2, 34-54.

Schwarzer, R., \& Jerusalem, M. (1995). Optimistic self-beliefs as a resource factor in coping with stress. In Extreme stress and communities: Impact and intervention (pp. 159-177). Springer, Dordrecht.

Shan, S., Ishaq, H. M., \& Shaheen, M. A. (2015), Impact of organizational justice on job performance in libraries: Mediating role of leader-member exchange relationship. Library Management, 36(1/2), 70-85. https://doi.org/10.1108/LM-01-2014-0003

Sopiah, S. (2008). Manajemen Bisnis Ritel (1st ed.). Yogyakarta: Andi.

Stajkovic, A. D., \& Luthans, F. (2003). Social cognitive theory and self-efficacy: Implications for motivation theory and practice. Motivation and Work Behavior, 126, 140.

Stajkovic, A. D., Bandura, A., Locke, E. A., Lee, D., \& Sergent, K. (2018). Test of three conceptual models of influence of the big five personality traits and self-efficacy on academic performance: A meta-analytic path-analysis. Personality and Individual Differences, 120, 238-245. https:// doi.org/10.1016/j.paid.2017.08.014

Suliman, A., \& Al Kathairi, M. (2013). Organizational justice, commitment and performance developing countries: The case of the UAE. Employee Relations, 35, 98-115. https:/doi. org/10.1108/01425451311279438

Suratman, B., Wulandari, S. S., Trisnawati, N., \& Narmaditya, B. S. (2020). Does teacher certification promote work motivation and teacher performance? A lesson from Indonesia. International Journal of Innovation, Creativity and Change, 11(10), 516-525.

Swalhi, A., Zgoulli, S., \& Hofaidhllaoui, M. (2017). The influence of organizational justice on job performance. Journal of Management Development, 36(4), 542-559. https://oi.org/10.1108/ JMD-11-2015-0162

Van Dyne, L., Graham, J. W., \& Dienesch, R. M. (1994). Organizational citizenship behavior: Construct redefinition, measurement, and validation. Academy of management Journal, 37(4), 765-802. https://doi.org/10.5465/256600

Walumbwa, F. O., \& Hartnell, C. A. (2011). Understanding transformational leadership-employee performance links: The role of relational identification and self-efficacy. Journal of Occupational and Organizational Psychology, 84(1), 153-172. https://doi.org/10.1348/096317910X485818

Wang, X., Liao, J., Xia, D., \& Chang, T. (2010). The impact of organizational justice on work performance. International Journal of Manpower, 31(6), 660-677. https://doi. org/10.1108/01437721011073364

Yusuf, M. (2011). The impact of self-efficacy, achievement motivation, and self-regulated learning strategies on students' academic achievement. Procedia-Social and Behavioral Sciences, 15, 2623-2626. https://doi.org/10.1016/j.sbspro.2011.04.158

Zhang, Z. J., Zhang, C. L., Zhang, X. G., Liu, X. M., Zhang, H., Wang, J., \& Liu, S. (2015). Relationship between self-efficacy beliefs and achievement motivation in student nurses. Chinese Nursing Research, 2(2-3), 67-70. https://doi.org/10.1016/j.cnre.2015.06.001 


\title{
Organizacinio teisingumo, saviveiksmingumo ir mokytoju veiklos poveikis: vidinès motyvacijos vaidmuo
}

\author{
Sopiah $^{1}$, Etta Mamang Sangadji ${ }^{2}$, Bagus Shandy Narmaditya ${ }^{3}$
}

1 Valstybinis Malango universitetas, Ekonomikos fakultetas, Semarango g. 5, Malangas, ID-65145, Indonezija, sopiah.fe@um.ac.id

2 Valstybinis PGRI Vira Negaros universitetas, Ekonominio švietimo bakalauras, Jl. Ki Hajar Dewantoro g. 27-29 Pasuruanas, Indonezija, sangadji_23@yahoo.com

3 Malango valstybinis universitetas, Ekonomikos fakultetas, Semarango g. 5, Malangas, ID-65145, Indonezija, bagus.shandy.fe@um.ac.id

\section{Santrauka}

Šiuo tyrimu siekiama nustatyti organizacinio teisingumo ir saviveiksmingumo įtaką mokytojų veiklai Indonezijoje, taip pat ištirti vidinès motyvacijos svarbą. Atliekant tyrimą buvo taikomas kiekybinis tyrimo metodas naudojant kelio analizę (angl. path analysis), vieną iš sudètinių struktūrinių lygčių analizės dalių, kuri padeda ịvertinti tiriamų kintamųjų ryšius. Tyrimo dalyviai - Indonezijos Rytų Javos profesinių mokyklų mokytojai. Gauti rezultatai rodo, kad ir mokytojai, ir mokyklų vadovai turi daug žinių apie organizacijos teisingumą, efektyvumą, vidinę motyvaciją ir mokytojų veiklą. Kaip rodo tyrimas, ir organizacinis teisingumas, ir saviveiksmingumas gali paveikti mokytojų veiklą ir būti susiję su vidine motyvacija. Vis dèlto vidine motyvacija yra tik dalinis organizacijos teisingumo ir mokytojo veiklos, taip pat saviveiksmingumo ir mokytojo veiklos tarpininkas. Rezultatai rodo, kad Indonezijos mokyklu vadovai ir politikos formuotojai atkreipia dėmesị i organizacijos teisingumo, saviveiksmingumo ir vidinès mokytojų motyvacijos gerinimą, nes šie komponentai turi didelę įtaką geresnei veiklai ir mokytojų atestavimo programai.

Esminiai žodžiai: vidine motyvacija, organizacinis teisingumas, saviveiksmingumas, mokytojo veikla.

Gauta 20200918 / Received 18092020

Priimta 20210218 / Accepted 18022021 